УДК 361(44)

DOI:

Юлія Возна, кандидат педагогічних наук, доџент кафедри соиіальної роботи і соиіальної педагогіки Хмельнищького національного університету

\title{
СОЦІАЛЬНА АНІМАЦІЯ У КОНТЕКСТІ ПРОФЕСІЙНОЇ ДІЯЛЬНОСТІ ФАХІВЦІВ СОЦІАЛЬНОЇ СФЕРИ У РІЗНИХ КРАЇНАХ СВІТУ
}

У статті висвітлюються проблеми змістових характеристик сочіально-анімачійної професійноі діяльності фахівців соиіальної сфери у різних країнах світу. Автор аналізує зміст соціальної освіти у практичному ї̈ відображсенні. Проводиться аналіз загальних засад діяльності соціального працівника у різних країнах світу. Автор наводить приклади соиіокультурної анімації у практичній діяльності фахівців соиіальної сфери за рубежем. Акцентується увага на досвіді соиіокультурної анімачії у Франції, розглядаються моделі анімаційної діяльності фахівиів соціальної сфери.

Ключові слова: анімація; сочіокультурний аніматор; спеціаліст дозвіллєвої сфери; сочіальна сфера; фахівець соиіальної сфери.

Jim. 5.

Juliya Vozna, Ph.D.(Pedagogy), Associate Professor of the Social Work and Social Pedagogy Department Khmelnytskiy National University

\section{SOCIALANIMATION IN THE CONTEXT OFTHE PROFESSIONALACTIVITIES OF SPECIALISTS OF THE SOCIAL SPHERE IN DIFFERENT COUNTRIES OF THE WORLD}

The article deals with the problems of the meaningful characteristics of socio-animated professional activities of specialists of social sphere in different countries. The author analyzes the content of social education in its practical reflection. The article analyzes the general principles of activities of social worker in different countries of the world. The author gives the examples of socio-cultural animation in the practical work of specialists of social sphere abroad. The article focuses on the experience of socio-cultural animation in France, examines the models of animation activities of specialists in the social sphere. The article analyzes the sphere of activity of social animators in France: - socioeconomic, where animators cooperate with various state and public organizations and associations; - association in residential neighborhoods - cultural, public and social centers, youth centers, leisure clubs, municipal departments for youth affairs, etc.; - special associations for certain categories of the population; - organization of tourism and rest. The author examine the content of cultural and leisure activities of social workers from such countries as Belgium, Switzerland, Italy, Spain, Turkey, Germany, Great Britain, Canada, Finland. The article deals with the concept of animation in the context of the professional activity of the free time teacher, analyzes relevant skills, knowledge and competencies. The author highlights the conceptual ideas of professional training of specialists for socio-cultural animation: the ideas of professionalism and the idea of protecting human rights. The article considers the characteristics of the "socio-animation" concept in German-speaking countries as an upgrading of the skills of social workers in the field of mediation between leisure-occupancy workers and marginalized groups of society. The article deals with different approaches to understanding the professional competence of specialists in the social sphere and analyzes various skills in the field of socio-cultural animation in different countries of the world.

Keywords: an animation; a socio-cultural animator; a specialist in leisure sphere; social sphere; a specialist in social sphere.

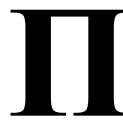
остановка й обгрунтування актуальності проблеми. Домінуючою концепцією будь-якого сучасного розвиненого суспільства $є$ створення ефективної системи соціального захисту та допомоги найбільш вразливих та найменш пристосованих до реалій сучасного життя категорій населення. Концепція соціальної допомоги та захисту $є$ основою стабільності та розвитку суспільств усіх держав світу. Тому саме соціальна робота $\epsilon$ тією професійною ланкою, що спроможна вирішувати багатогранний спектр соціальних запитів, потреб та проблем сучасного суспільства. Оскільки соціальна сфера $є$ багатогранною, динамічною та мобільною, то відповідно і професійна діяльність цієї сфери повинна конструктивно вирішувати різносторонні соціальні завдання. Одним 3 пріоритетних завдань соціальної роботи $€$ якісна організація дозвіллевої діяльності дітей та молоді. Питання про статус спеціаліста дозвіллєвої сфери є сьогодні пріоритетним. Це пояснюється об'єктивною потребою сучасного суспільства в особливій категорії працівників соціокультурної сфери, професіоналів, які працюють у відкритому мікросоціальному середовищі, спеціалізуються на дозвіллєвій та рекреаційній діяльності, вміють надавати психолого-педагогічну допомогу сім'ям та окремим індивідам та здатні вирішувати освітні 


\section{СОЦІАЛЬНА АНІМАЦІЯ У КОНТЕКСТІПРОФЕСІЙНОӤ ДІЯЛЬНОСТІ ФАХІВЦІВ СОЦІАЛЬНОӤ СФЕРИ У РІЗНИХ КРАЇНАХ СВІТУ}

та соціально-виховні завдання, впливати на формування суспільної свідомості.

Аналіз основних досліджень і публікацій. Проблеми анімаційної діяльності фахівців соціальної сфери вирішують такі науковці як: В.А. Поліщук, Н.В. Волкова, Є.Г. Дорокіна, С.Н. Іконнікова, В.В. Кірсанов, У. Лоренц, С.Б. Мамбеков, О. Пічкар, В.М. Чижикова та ін.

Метою статті $\epsilon$ розкриття змістових характеристик анімаційної діяльності фахівців соціальної сфери у різних країнах світу.

Виклад основного матеріалу. Парадигма соціально-культурної освіти в останні десятиліття суттєво змінилася в усьому світі, що пояснюється орієнтацією на принципово нове розуміння культури та їі ролі в освітній системі. Соціальна освіта у практичномуії відображенні - соціальній роботі, охоплює багато сфер життєдіяльності кожної людини, починаючи 3 дошкільного виховання, підтримки та захисту, супроводжуючи людину протягом усього іiї життя.

Функціонування інституту соціальної роботи є необхідною умовою нормального розвитку суспільства: вирішуючи соціальні проблеми, вона забезпечує гармонізацію суспільних відносин i, перш за все, відносин між людиною та суспільством. На думку вчених та практиків, соціальна робота повинна підтримувати соціальний добробут країни, задовольняти широке коло соціальних потреб людей, забезпечувати рівні можливості для різних соціально-економічних класів, вікових і статевих груп, національних i сексуальних меншин, людей різних політичних переконань та інших особливостей.

Основна мета професії "соціальна робота" сприяння соціальним змінам у суспільстві загалом та в окремих індивідах зокрема. Реалізація такого подвійного призначення соціальної роботи $\epsilon$ можливою завдяки ії посередницькому характеру, який полягає унормалізації відносин між людиною і державою.

Більшість провідних фахівців різних країн світу наголошують на необхідності уточнення поняття “соціальна робота", оскільки сьогодні надання гарантованої соціальної допомоги людині, задоволення їі мінімальних потреб та благодійна допомога тим, хто знаходиться за межею бідності - вже не є їі основним змістом. Соціальна робота починається тоді, коли клієнт включається у самостійне вирішення своїх проблем, і власне у цьому полягає основна функція соціальної роботи як професії.

Поряд із загальними засадами діяльності соціального працівника у кожній державі сформувалися притаманні лише їй аспекти та особливості роботи в соціальній сфері. Проаналізуємо зміст професійної діяльності фахівців соціальної сфери у контексті анімації у різних країнах світу.

Для нашого дослідження цінним є досвід організації соціально-анімаційної діяльності у Франції, де система підготовки працівників соціальної сфери є однією із найбільш ефективних у світі. Компетентність у різних галузях соціальної діяльності, як правило, все ж передбачає спеціалізацію у якійсь одній із них і це визначає основні професійні ролі соціального працівника: консультант (проводить психологічні та соціальні консультації, бесіди), брокер (надає необхідну інформаційну підтримку - підказує клієнту, до яких служб слід звернутися за допомогою), захисник (відстоює інтереси клієнта в різноманітних інстанціях), опікун (опікується дітьми-сиротами, дітьми із неблагополучних родин, доглядає хворих та осіб похилого віку), посередник (соціальний працівник, який знаходиться між двома людьми, людиною та групою з метою допомогти їм вирішити спільні проблеми), розпорядник (визначає суспільні групи та окремих індивідів, які потребують підтримки, і займається призначенням як матеріальної, так і соціальної допомоги ) та ін. Соціокультурна анімація у Франції сприймається як активна, творча організація вільного часу, яка орієнтована на формування загальної культури особистості, віри в свої можливості, розвиток творчих здібностей, активізацію процесу спілкування, самопізнання, самореалізації та самовдосконалення. Поле діяльності аніматорів у Франції умовно включає чотири сфери: соиіально-економічну (наприклад, нові міста великого Парижу - Сержі-Понтуаз, Еврі, Марнля-Валле та ін.), де аніматори співпрацюють 3 різними державними та громадськими організаціями та об'єднаннями; - об'єднання в житлових кварталах - культурні, громадські та суспільні центри, будинки молоді і культури, клуби дозвілля, муніципальні відділи із справ молоді тощо; - спеціальні об 'єднання для окремих категорій населення (дитячі будинки, будинки пристарілих, спеціалізовані інтернати і т. ін.); організації туризму й відпочинку, туристичні літні бази, табори, сімейні будинки і т.д. Професійна підготовка аніматорів соціальної та соціокультурної діяльності відбувається як у державних, так і в приватних спеціальних навчальних закладах [2].

У контексті нашого дослідження важливим до аналізу є досвід соціокультурної анімації у Швейцарії. Поняття “соціально-культурна 


\section{СОЦІАЛЬНА АНІМАЦІЯУ КОНТЕКСТІПРОФЕСІЙНОЇ ДІЯЛЬНОСТІ ФАХІВЦІВ СОЦІАЛЬНОӤ СФЕРИ У РІЗНИХ КРӒ̈НАХ СВІТУ}

анімація” визначається швейцарськими вченими як свідома діяльність, спрямована на розвиток і зміну соціального спілкування дітей, соціальних структур та вдосконалення умов для дій окремих індивідів, соціальних груп та більш повної реалізації потенціалу різнобічних людських можливостей.

Анімація розглядається як складова частина всієї соціальної діяльності, як нова соціальна професія. Вона включає усю проблематику вільного часу, а також проблеми молодіжного руху, спрямована на створення автономних молодіжних центрів.

На даний час у Швейцарії у сфері соціальнокультурної анімації існує більше 2 тис. різного роду закладів і центрів. Сферами діяльності соціальних аніматорів є молодіжні клуби, дитячі і юнацькі організації, громадські центри, заклади дозвілля, різноманітні культурні центри. Новою формою анімації $\epsilon$ робота в житлових кварталах, спрямована на поліпшення умов життя у певному жилому просторі. У Швейцарії існує градація між соціальними працівниками і соціальними педагогами, а також спеціалістами у сфері дозвілля, аніматорами. Школи із підготовки даних спеціалістів об'єднуються в асоціації. Таким чином, у Швейцарії створена Асоціація шкіл соціальної педагогіки, яка об'єднує 14 шкіл, Асоціація шкіл соціальної роботи - 10 шкіл, Асоціація шкіл соціокультурної анімації - 4 школи. Поза рамками асоціації існує університет 3 підготовки соціальних педагогів.

Специфіку підготовки соціальних працівників у Швейцарії обумовлює той факт, що зміст, форми i методи соціальної роботи здебільшого обумовлюються недержавними ініціативами на місцевому рівні та на рівні кантонів. Власне тому і швейцарські школи соціальної роботи у більшості випадків створюються на рівні кантонів, а інколи і на рівні кількох кантонів. Жодна із шкіл соціальної роботи не $є$ федеральною, і жодна 3 них не $\epsilon$ державною школою .

У Швейцарії на 25 кантонів припадає лише 10 шкіл соціальної роботи. Всі вони дають освіту на рівні коледжу. Як уже зазначалося, соціальних працівників готує один університет, проте він працює за програмою соціальних наук в цілому і не входить у Швейцарську Асоціацію шкіл соціальної роботи. Членом цієї організації може стати будь-яка школа, яка визнає вимоги Асоціації щодо рівня і якості підготовки соціальних працівників.

Деякі кантони (чи групи кантонів) створюють школи, які готують спеціалістів для трьох основних сфер - соціальної роботи, соціальної педагогіки і соціальної анімації. Такі школи можуть бути членами усіх трьох асоціацій: Асоціації шкіл соціальної роботи, Асоціації шкіл соціальної педагогіки та Асоціації соціокультурної анімації. Останнім часом у Швейцарії спостерігається тенденція до об'єднання цих асоціацій. Кожна школа підпорядковується перш за все уряду кантону і організаціям, які мають статус фондів чи асоціацій.

Оскільки підготовка кадрів для системи соціальної служби у Швейцарії здійснюється на рівні коледжу, практично поза університетськими структурами, тому вона багато у чому схожа на існуючу в Європі систему. Проте в той же час вона відрізняється від системи підготовки соціальних працівників Канади і США, де вона $\epsilon$ частиною університетської підготовки.

Необхідно зазначити, у більшості зарубіжних країн дозвіллєва та рекреаційна професійна діяльність фахівців соціальної сфери розглядається як невід'ємна складова усього спектру соціальних та культурних послуг. Так, професія спеціаліста дозвіллєвої сфери у франкомовних частинах Бельгії Італії, Іспанії, Туреччині здобула назву “аніматора”. “Анімація поєднала оновлення та демократизацію хоча б тому, що дозвілля, у тому числі й “примусове”, викликане тривалим безробіттям, може перетворитись на джерело конфлікту, якщо доступ до окремих видів діяльності $\epsilon$ надто нерівномірним” [3]. “Анімація - це форма соціальної практики, спрямована на усвідомлення та розкриття пригнобленого та дрімаючого потенціалу індивідів, малих груп та спільнот" [3]. Поняття “анімація” починає використовуватися й у німецькомовних країнах. Наприклад, 1989 року Віденська академія соціальної роботи запропонувала для підвищення кваліфікації соціальних працівників ввести післядипломний курс під назвою “Соціоанімація”. Це була спроба ввести в дію методологію, яка б стимулювала творчість, відкритість та партнерство в роботі з населенням, допомогла уникнути непорозумінь між працівниками дозвіллєвих закладів та маргінальними групами суспільства.

У Великобританії спеціаліста дозвіллєвої сфери називають “соціальний працівник”, “спеціаліст по роботі з молоддю у громаді”.

У Канаді спеціаліста дозвіллєвої сфери називають “соціальний працівник”, у Норвегії виділяють три професійних та освітніх рівні підготовки таких фахівців: соиіонома (який працює в місцевих організаціях, дбаючи про соціальну безпеку), сочіального педагога (який організовує соціально-культурну діяльність 3 


\section{СОЦІАЛЬНА АНІМАЦІЯУ КОНТЕКСТІПРОФЕСІЙНОЇ ДІЯЛЬНОСТІ ФАХІВЦІВ СОЦІАЛЬНОЇ СФЕРИ У РІЗНИХ КРАЇНАХ СВІТУ}

дітьми та підлітками) і соц̧іального праціівника (який здійснює соціально-культурну діяльність серед інвалідів) [1].

До професій соціальної сфери уФРН належать: помічник соціального працівника по догляду за людьми літнього віку; соціальний працівник по догляду за людьми літнього віку; психотерапевт 3 дитячих і юнацьких проблем; дипломований педагог; помічник по веденню домашнього господарства на селі; консультант 3 сімейних питань; вихователь; помічник по сімейному побуту; помічник у справі виховання дітей; соціальний працівник по догляду за інвалідами; вихователь дитячого будинку; організатор дозвілля дітей і молоді; відповідальний працівник по роботі з молоддю на місцях (особа, відповідальна за втілення молодіжної політики ФРН у місцевих органах самоврядування); працівник у справах дітей і юнацтва; консультант 3 питань реабілітації; соціальний педагог; соціальний працівник у справах іноземців.

Необхідно відзначити, що у той час як у більшості країн використовується лише одне поняття “соціальна робота" для позначення професії, у Федеративній Республіці Німеччини поширеними $є$ обидва поняття - i “соціальна робота" і “соціальна педагогіка”. Соціальна робота - більш широке поняття, яке включає також педагогічні впливи і діяльність по захисту людини, по наданню їй допомоги. Соціальна ж педагогіка позначає лише сфери діяльності 3 педагогічними цілями, включаючи роботу 3 дорослими, томущо виховання й освіта - процеси, які супроводжують усе життя людини. Предметом соиіальної педагогіки є педагогічна робота 3 дітьми, підлітками і дорослими. Тому в роботі з клієнтами ставляться педагогічні цілі. Так діти проводять частину дня в дитячому саду.

Термін “педагог вільного часу” формується у Німеччині в 30-і роки XX століття, однак спеціальна їх підготовка здійснюється лише з 70-х років XX ст. у вищих навчальних закладах (як і працівників молодіжних центрів) та на курсах педагогіки, вільного часу й туристики. Педагог вільного часу розглядається німецькими вченими та практиками як працівник високої кваліфікації у сфері послуг. Його головним завданням $є$ організація дозвілля та спілкування населення. А тому педагог вільного часу повинен вміти порозумітися з представниками різних соціальнодемографічних угруповань, розпізнавати й аналізувати потреби та інтереси відвідувачів соціально-культурних установ, сприяти їх задоволенню, допомагати вирішувати різноманітні проблеми підлітків та молоді, спрямовувати клієнта на прийняття самостійних рішень (але таких, які не суперечать педагогічним основам); систематично та цілеспрямовано залучати до соціально-культурної творчості самотніх людей, створювати в колективі дружню, доброзичливу атмосферу, здійснюючи при виконанні своїх функціональних обов'язків педагогічний вплив [5].

Німецькі вчені В. Нарштедт та Ю. Зандерманн зазначають, що, незважаючи на суспільну потребу у висококваліфікованих спеціалістах дозвіллєвої сфери, професія педагога вільного часу ще повністю не сформувалася [4].

Незважаючи на розбіжності, спільним у кадровій політиці зарубіжних держав є те, що професійна підготовка спеціалістів для дозвіллєвої сфери грунтується на двох фундаментальних началах: - ідеї професіоналізму та ідеї захисту прав людини.

Більшість зарубіжних фахівців вказують на те, що спеціаліст дозвіллєвої сфери, іншими словами соціальний аніматор, повинен бути готовим до систематичних робочих перевантажень. Це пояснюється сутністю самої професії та іiї значимістю в сучасному суспільстві: великих зусиль потребує удосконалення господарських служб соціально-культурних закладів, придбання технічного обладнання, пошук джерел фінансових надходжень, координація роботи з іншими закладами району, протидія постійному тиску 3 боку влади та різних організацій.

Висновки. Про ефективність та перспективність діяльності аніматорів свідчить зростаючий інтерес до професії аніматора в різних країнах світу i запозичення зарубіжного досвіду при організації соціокультурної анімаційної діяльності фахівців соціальної сфери. Тому акцентувати увагу на значущості соціокультурної анімації варто через призму підготовки фахівців для соціальної сфери. Робота спеціаліста анімаційно-дозвіллєвої сфери ускладнюється необхідністю працювати 3 представниками різних соціальних груп та інститутів. Ці обставини зумовили істотне розширення освітнього спектру в соціокультурній сфері, відмову від пріоритетної орієнтації на формування спеціалістів теоретичного профілю та привернули серйозну увагу до практичної підготовки кадрів дозвіллєвої сфери.

Рекомендації. Вивчення міжнародного досвіду дозволяе виділити загальні вимоги до особистості соціального працівника та визначити найбільш ефективні моделі організації соціальної роботи, що містять перспективи та можливості для їх подальшої адаптації у власній країні. Закордонний досвід соціальної роботи представляє для нас, безсумнівно, значний і теоретичний, i 


\section{СОЦІАЛЬНА АНІМАЦІЯУ КОНТЕКСТІПРОФЕСІЙНОӤ ДІЯЛЬНОСТІ ФАХІВЦІВ СОЦІАЛЬНОЇ СФЕРИ У РІЗНИХ КРАЇНАХ СВІТУ}

практичний інтерес. Але при цьому ми повинні усвідомлювати необхідність розробки власних технологій соціальної роботи з урахуванням історичного розвитку і сучасного стану країни.

В умовах сучасної системи навчання у вищій школі у галузі соціальної роботи сформованість у студентів професійних якостей та вмінь виявляється недостатньою для ефективної практичної діяльності в майбутньому, зокрема у соціокультурній діяльності. Зважаючи на такі реалії сучасної соціальної освіти рекомендуємо впровадження в навчальний процес підготовки фахівців інноваційних форм та методів навчання 3 акцентом на зарубіжний досвід змістових характеристик соціально-культурної анімаційної діяльності.

Перспективи подальших досліджень. Напрями подальших досліджень окресленої проблеми полягають у розробці соціальноорієнтованих навчально-дослідних умов формування професійно важливих якостей майбутніх фахівців у процесі поєднання теоретичної підготовки та опори на соціокультурну діяльність фахівців для соціальної сфери.

\section{ЛІТЕРАТУРА}

1. Доронкина Е. Г. Проблема профессиональной подготовки кадров для сферы досуга: зарубежный опыт // Социально-культурная деятельность: поиски, проблемы, перспективы. - М., 1999.

2.Иконникова С. Н.,Новикова И. А. Международный опыт педагогической подготовки специалистов сферы досуга // Вестник Северо-запад. отделения Рос. акад. образования. - СПб., 1998. - Вып. 3.

3. Пічкар О. Підготовка соціальних працівників у Великобританії // Соціальна політика і соціальна робота. - 2002. - №3-4. - С. 26-31.

4. ЮНЕСКО: Деятельность в области образования во всем мире. Париж, 1994.

5. Torkildsen G. Leisure and Recreation Management. - London - New York, 1983.

\section{REFERENCES}

1. Doronkina, Ye. G. (1999). Problema professionalnoy podgotovki kadrov dlya sfery dosuga: zarubezhnyy opyt [The problem of professional training for leisure: foreign experience]. The social and cultural activities: searches, problems, and prospects. Moscow. [in Russian].

2. Ikonnikova, S. N. \& Novikova, I. A. (1998). Mezhdunarodnyy opyt pedagogicheskoy podgotovki spetsialistov sfery dosuga [International experience of pedagogical training of specialists in the sphere of leisure]. A Herald of the Northwest Branch of Russian Academy of Education.St.Petersburg. Vol.3. [in Russian].

3. Pichkar, O. (2002). Pidhotovka sotsialnykh pratsivnykiv u Velykobrytanii [Preparation of social pracivnik at Great Britain]. Social policy and social work. No.3-4, pp. 26-31. [in Ukrainian].

4. YuNYeSKO: Deyatelnost v oblasti obrazovaniya vo vsem mire [UNESCO: Worldwide Education Activities]. Parizh, 1994. [in Russian].

5. Torkildsen, G. (1983). Leisure and Recreation Management. London - New York. [in English].

Стаття надійшла до редакції 16.11.2018

\section{G5808ר

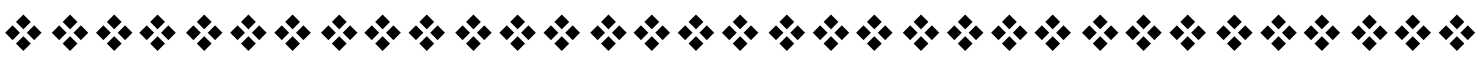

"S̆ торкаюся майбутнвого. Я્ виу".

Kріста Маколіббб американський педагог

"Мистецтво навчання є мистеитво пробуджувати в юних душах допитливість $i$ потім задовольняти ї̈”.

Анатоль Франс

франиузький прозаїк

“Без приқладів неможливо ні правильно вчити, ні успішно вчитися”.

Ауиій Юній Модерат Колумелла давнъоримський письменник

\section{$\% * \% * \% * \%$

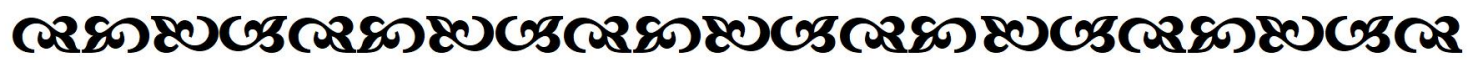

